calcium level was profound. This might be expected to sensitize the myocardium (Meroney and Herndon, 1954) to the rise in plasma potassium that may occur in any patient with renal failure who has had a major operation. This combination of events was presumably responsible for the death of Case 4. The postoperative fall in plasma phosphate is the opposite to what is seen in patients who have had a parathyroidectomy for primary hyperparathyroidism. This was found also by Stanbury et al. (1960), who pointed out that, as the normal phosphaturic effect of exogenous parathyroid hormone does not occur in the presence of a reduction in creatinine clearance to less than $10 \mathrm{ml} . /$ minute (Goldman and Bassett, 1954), parathyroidectomy would not be expected to change the renal phosphate clearance. Though the urinary excretion of phosphate fell postoperatively in all the patients, the fall was no greater than would be expected from that in the plasma level, and presumably the fall in the plasma level is due to the deposition of phosphate with calcium in bone.

The practical problems imposed by the appearance of autonomous hyperparathyroidism after successful renal transplantation are considerable. At least one transplanted kidney has been affected by calculi associated with autonomous (secondary) hyperparathyroidism (Hume et al., 1966), and in any case the dangers of parathyroidectomy must be increased considerably by the immunosuppressive and steroid therapy that these patients receive. Thus if the presence of hyperparathyroidism is recognized it is probably advisable to deal with it before embarking upon transplantation.

\section{Summary}

Previous experience of the use of parathyroidectomy in the treatment of secondary (renal) hyperparathyroidism has been reviewed briefly. Four further cases are reported, and it is suggested that, with increasing interest in the management of chronic renal failure, the operation may be performed more often in the future than it has been in the past. The indications for and the timing of surgery are discussed.

I wish to thank Dr. A. M. Joekes and Dr. A. R. Harrison for permission to report these cases. Mr. J. D. Fergusson performed all the operations and Dr. L. Watson carried out the plasma calcium fractionations.

\section{REFERENCES}

Anderson, W. W., Mann, J. B., Kenyon, N., Farrell, J. J., and Hills, A. G. (1963). New Engl. ₹. Med., 268, 575

Ball, J. (1960). In Recent Advances in Pathology, 7th ed., edited by C. V. Harrison. London.

Davies, D. R., Dent, C. E., and Willcox, A. (1956). Brit. med. F., 2,

de Wesselow, O. L. V. (1923). Ibid., 16, 341.

de Wesselow, O. L. V. (1923). Ibid., 16, 341. 30, 1., A., and Rose, G. A. (1958). Ibid., 27, 463.

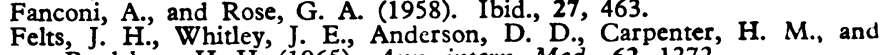
Bradshaw, H. H. (1965). Ann. intern. Med., 62, 1272.

Findley, T., Moore, J. D., and Brackney, E. L. (1961). Lancet, 2, 1150. Fordham, C. C., and Williams, T. F. (1963). New Engl. J. Med., 269,

129.
Gilmour, J. R. (1947). The Parathyroid Glands and Skeleton in Renal Disease. London.

Golden, A., Canary, J. J., and Kerwin, D. M. (1965). Amer. F. Med., 38 , 562.

Goldman, R., and Bassett, S. H. (1954). F. clin. Invest., 33, 1623.

Hubbard, R. S., and Wentworth, J. A. (1921). Proc. Soc. exp. Biol (N.Y.), 18, 307

Hume, D. M., et al. (1966). Ann. Surg., 164, 352.

Liu, S. H., and Chu, H. I. (1943). Medicine (Baltimore), 22, 103.

McIntosh, D. A., Peterson, E. W., and McPhaul, J. J. (1966). Ann. intern. Med., 65, 900.

McPhaul, J. J., McIntosh, D. A., Hammond, W. S., and Park, O. K. (1964). New Engl. 7. Med., 271, 1342.

Meroney, W. H., and Herndon, R. F. (1954). F. Amer. med. Ass., 155 , 877 .

Shelling, D. H., and Remsen, D. (1935). Bull. fohns Hopk. Hosp., 57. 158.

Smyth, F. S., and Goldman, L. (1934). Amer. F. Dis. Child., 48, 596.

Stables, D. P., Levin, N. W., Rubenstein, A. H., Berk, M. E., and Abrahams, C. (1964). Ann. intern. Med., 61, 531.

Stanbury, S. W., and Lumb, G. A. (1962). Medicine (Baltimore), 41, 1. (1966). Quart. F Med., 35, 1.

二- and Nicholson, W. F. (1960). Lancet, 1, 793.

Walser, M. (1962). F. clin. Invest., 41, 1454.

Wilson, R. E., Bernstein, D. S., Murray, J. E., and Moore, F. D. (1965) Amer. F. Surg., 110, 384.

\title{
Syndrome of Sclerodactyly, Calcinosis, Raynaud's Phenomenon, and Telangiectasia
}

\author{
A. W. DELLIPIANI,* M.B., M.R.C.P.ED. ; M. GEORGE, † M.B., B.SC., M.R.C.P., M.R.C.P.ED.
}

Brit. med. F., 1967, 4, 334-335

Since Thibierge and Weissenbach (1911) described the association between scleroderma and calcinosis the ThibiergeWeissenbach syndrome has come to mean anything from progressive systemic sclerosis with calcinosis (Durham, 1928) to a much more benign syndrome in which sclerodactyly, calcinosis, and Raynaud's phenomenon are associated with telangiectasia (Prosser Thomas, 1942). In the 10 years preceding 1964 only 18 cases with this clearly defined syndrome had been reported, and to these Winterbauer (1964) added another seven. The present report describes three further cases and reviews the prognosis in this syndrome.

\section{Case 1}

A 66-year-old woman gave a history of Raynaud's phenomenon in the hands since the age of 20 , which had been more of an inconvenience than a disability. The most recent admission was caused by an exacerbation of dyspnoea, which had been present for * Department of Therapeutics, the Royal Infirmary, Edinburgh 3.
t Department of Cardiology, the Royal Infirmary, Edinburgh 3. two to three years. There was no family history of telangiectasia or of recurrent haemorrhagic episodes to suggest this.

Some rheumatoid deformity was present in the hands, there was also sclerodactyly and a thickened subcutaneous plaque in the left forearm. Telangiectatic spots were present on the lips, the buccal mucosa, and the hands. Other abnormal findings were a raised jugular venous pressure and a cardiac apex in the sixth space outside the midclavicular line, the impulse being left ventricular in type. A mitral grade III regurgitant systolic murmur was audible at the apex with a third heart sound. Marked dorsal kyphosis was present, and the liver was enlarged one fingerbreadth and was soft.

The abnormal findings on investigation were that the chest $x$-ray film showed left ventricular enlargement with pulmonary congestion. Radiographs of the hands showed contractures of the thumbs and fifth fingers of both hands with soft-tissue calcification in the fingers (see Fig.). Respiratory function tests demonstrated impaired vital capacity $(1,350 \mathrm{ml}$.; predicted $1,900 \mathrm{ml}$.) with increased residual volume $(2,460 \mathrm{ml}$; predicted 1,800 ml.). There was evidence of obstructive airway disease, the ratio F.E.V.1/F.V.C. being $56 \%$. $\mathrm{O}_{2}$ saturation was $86 \% ; \mathrm{PcO}_{2} 38 \mathrm{~mm}$. $\mathrm{Hg} ; \mathrm{pH} 7.40$. The findings were thought to be compatible with the presence of pulmonary congestion and kyphoscoliosis. 


\section{Case 2}

A 51-year-old woman gave a 30-year history of Raynaud's phenomenon. At times she had developed white lumps in the fingers, which were incised and took months to heal. In 1942 she had a right-sided cervical sympathectomy and 20 years later a rightsided lumbar sympathectomy for ischaemic symptoms in the feet. In addition, she had had the right index and middle fingers amputated, and in 1959 a local excision of a palatal angiomatous lesion because of recurrent bleeding. The most recent admission was caused by an exacerbation of ischaemic symptoms in the hands. Thene was no history of telangiectasia or of recurrent epistaxes, haemoptyses, or haematemeses in the family.

She was a thin woman, and had sclerodactyly with marked softtissue calcification. Telangiectatic spots were noted on the lips and the buccal mucosa. The blood pressure was 180/100 mm. Hg.

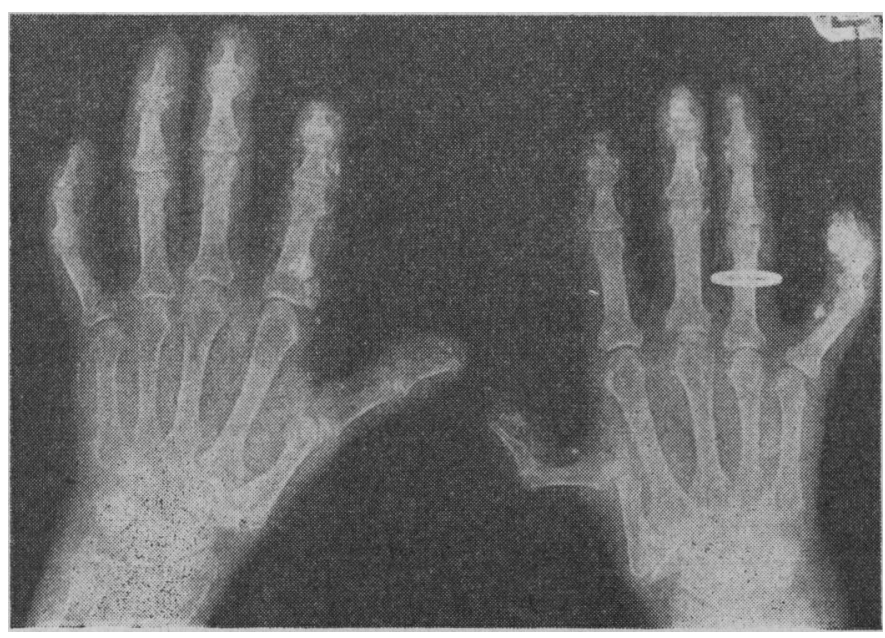

Radiograph of hands in Case 1.

The abnormal findings on investigation were that $x$-ray films of the hands showed marked calcification of the soft tissues. $X$-ray film of the chest showed slight cardiomegaly and the changes of chronic bronchitis and emphysema, while barium swallow showed slight oesophageal atony and dilatation.

Two of the patient's siblings examined by us were normal.

\section{Case 3}

A 35-year-old woman gave a 15-year history of Raynaud's phenomenon in both hands. In the previous three months this had become worse, and she had developed ulcers on the third digits of both hands. She had had varicose veins since the birth of the first of her three children nine years previously, and the immediate cause for admission was the development of a superficial thrombosis of the long saphenous vein in the left leg. There was no previous history of jaundice and no history to suggest telangiectasia in the family, which included four brothers and one sister.

Sclerodactyly was present with ulceration of the skin of both third digits. Telangiectatic spots were present on the lips and the surrounding skin, on the buccal mucosa, and on the hands.

The abnormal results of investigation were as follows: Serum alkaline phosphatase 76 and 63 K.A. units; S.G.P.T. 44 S.F. units; S.G.O.T. 54 S.F. units; 5-nucleotidase 181 and 141 i.u./1. The total serum proteins were $6.4 \mathrm{~g} . / 100 \mathrm{ml}$. (albumin $3.7 \mathrm{~g}$.), and the electrophoretic pattern: $\alpha_{1}$-globulin $0.2 \mathrm{~g} . / 100 \mathrm{ml}$; $\alpha_{2}$-globulin 0.9 g. $/ 100 \mathrm{ml}$; $\beta$-globulin 0.9 g. $/ 100 \mathrm{ml}$; and $\gamma$-globulin $0.7 \mathrm{~g} . / 100 \mathrm{ml}$. $X$-ray films of the hands showed decalcification and erosion of the heads of the middle phalanges on both sides and of the proximal phalanx of each middle finger. Calcification was present in the soft tissues of the middle fingers and the right index finger, mainly related to the interphalangeal joints.

None of the siblings lived in the area, and were therefore not examined. The patient's three children, aged 6 to 9 years, were examined and no telangiectatic lesions were noted.

\section{Discussion}

There is nothing to distinguish the telangiectasia in this condition, either in appearance or distribution, from the lesions in patients with hereditary telangiectasia. It has been suggested, however, that the lesions appear later than in the hereditary condition, where they usually occur in the second to the fourth decade-though they may be present in childhood (de Gruchy, 1964). It is also said that there is less tendency to haemorrhagic episodes, and that the telangiectatic lesions are not hereditary in this syndrome, where there is also a predominance of affected females (Winterbauer, 1964). None of our three patients gave any family history suggesting telangiectasia. Only Cases 1 and 3 could recall roughly when their lesions appeared, the former when well into her fifties and the latter just after the age of 20 . Only Case 2 had been troubled by bleeding, which originated from a palatal lesion.

The occurrence of signs of systemic scleroderma in the syndrome of sclerodactyly, calcinosis, Raynaud's phenomenon, and telangiectasia is well recorded. Case 2 had oesophageal involvement, while Case 3 had abnormal liver-function tests. Though the latter was initially treated with phenindione, the abnormal findings persisted a year after stopping this drug. Sclerodermatous hepatic involvement is said to be extremely rare (Tuffanelli and Winkelmann, 1961). Calvert et al. (1958) described two cases of severe portal hypertension associated with hepatic fibrosis in two patients with systemic fibrosis, and Batsakis and Johnson (1960) reported systemic scleroderma in a patient with a pulmonary adenocarcinoma who had hepatic fibrosis. We feel that the abnormalities in our patient are most likely to be due to sclerodermatous involvement of the liver. Because of the possibility of visceral telangiectasia hepatic biopsy was not attempted.

It has been emphasized that the progress of the disease in patients with this syndrome is slow even in the presence of systemic involvement (Winterbauer, 1964). Though rare, the syndrome appears to come under the general heading of " acrosclerosis" (Sellei, 1934). In contrast, diffuse scleroderma (progressive systemic sclerosis) is a rare condition (Tuffanelli and Winkelmann, 1961) with a poor prognosis, the five-year survival being of the order of $50 \%$ (Farmer et al., 1960).

\section{Summary}

Three cases of sclerodactyly, Raynaud's phenomenon, calcinosis, and telangiectasia are described. The syndrome appears to be a rare variant of the most common form of presentation of scleroderma "acrosclerosis." The occurrence of systemic manifestations is noted, but the fact that this type of scleroderma tends to run a relatively benign course is emphasized.

We would like to express our thanks to Dr. C. Burt, Mr. R. J. M. McCormack, and Professor R. H. Girdwood for permission to describe these cases.

\section{REFERENCES}

Batsakis, J. G., and Johnson, H. A. (1960). Arch. Path., 69, 633.

Calvert, R. J., Barling, B., Sopher, M., and Feiwel, M. (1958). Brit. med. F., 1, 22

de Gruchy, G. C. (1964). Clinical Haematology in Medical Practice, Chap. XIV, p. 539. Oxford.

Durham, R. H. (1928). Arch. intern. Med., 42, 467.

Farmer, R. G., Gifford, R. W., jun., and Hines, E. A., jun. (1960). Circulation, 21, 1088.

Sellei, J. (1934). Brit. F. Derm., 46, 523.

Thibierge, G., and Weissenbach, R.-J. (1911). Ann. Derm. Syph. (Paris), 2, 129.

Thomas, E. W. P. (1942). Lancet, 2, 389.

Tuffanelli, D. L., and Winkelmann, R. K. (1961). Arch. Derm., 84, 359.

Winterbauer, R. H. (1964). Bull. fohns Hopk. Hosp., 114, 361. 